Journal of Engineering and Applied Sciences 14 (13): 4317-4322, 2019

ISSN: 1816-949X

(C) Medwell Journals, 2019

\title{
Application of Nonlinear Autoregressive Distributed Lag (NARDL) Model for Analysis of the Asymmetric Effects of Real Exchange Rate Volatility on Vietnam's Trade Balance
}

\author{
${ }^{1,2}$ Le Hoang Phong, ${ }^{2}$ Ho Hoang Gia Bao and ${ }^{1}$ Dang Thi Bach Van \\ ${ }^{1}$ School of Public Finance, University of Economics Ho Chi Minh City, \\ 59C Nguyen Dinh Chieu, District 3, Vietnam \\ ${ }^{2}$ Department of Finance and Accounting Management, Ho Chi Minh City University of Law, \\ 02 Nguyen Tat Thanh, District 4, Vietnam
}

\begin{abstract}
Since, it was proposed by Shin, Yu and Greenwood-Nimmo (Festschrift in honor of Peter Schmidt: econometric methods and applications, Springer) the Nonlinear Autoregressive Distributed Lag (NARDL) approach originated from Pesaran, Shin and Smith has been employed by manifold recent studies to scrutinize the asymmetrical causality between independent and dependent variables. Expressly, NARDL is regarded as an appropriate method for examining whether the effects of exchange rate depreciation and exchange rate appreciation on trade balance are distinguishable which might be an imperative of Foreign trade policies. Phong, Bao and Van (Studies in computational intelligence: Econometrics for financial applications, Springer) evaluates the impact of exchange rate volatility on Vietnam's trade balance using the linear ARDL approach of Pesaran et al. and finds significant results. This study ameliorates our previous research by testing asymmetric effects of Vietnam's exchange rate volatility on trade balance using NARDL approach. The findings denote that short-run and long-run exchange rate volatility considerably impacts the trade balance of Vietnam. Indubitably, the trade balance of Vietnam responds more strongly to VND depreciation than to VND appreciation.
\end{abstract}

Key words: Nonlinear ARDL, asymmetric effects, exchange rate, trade balance, Vietnam, VND

\section{INTRODUCTION}

Exchange rate plays an important role in macroeconomic policies. Exchange rate devaluation is theoretically considered to encourage export, trade balance and economic growth of a country (Nusair, 2017). Magee (1973) and manifold other studies use the term "J-curve effect" or "J-curve phenomenon" to address the response of trade balance to exchange rate devaluation. Specifically, in the short run, trade balance declines due to the lagged adjustments of quantities to the change in prices in the long run, trade balance accrues resulting from the adjustment of quantities to prices.

Bahmani-Oskooee $(1985,1989)$ proposed a method for inspecting the existence of $\mathrm{J}$-curve phenomenon as evidenced by negative coefficients at lower lags preceding positive estimates at higher lags when adding lag structure of real exchange rate beside other macroeconomic factors.

Many a study has empirically scrutinized the J-curve phenomenon in various countries and regions but uniform findings are unobserved. Namely, Rose and
Yellen (1989), Rose (1990), Bahmani-Oskooee and Malixi (1992), Rose (1991), Bahmani-Oskooee and Brooks (1999), Bahmani-Oskooee and Goswami (2003), Bahmani-Oskooee and Ratha (2004), Bahmani-Oskooee and Wang (2006), Narayan (2006), Georgopoulos (2008), Bahmani-Oskooee and Kutan (2009), Hsing and Sergi (2010), Bahmani-Oskooee and Hegerty (2010), Bahmani-Oskooee and Gelan (2012) and Ziramba and Chifamba (2014) detect no J-curve effect. In contrast, researches instanced to testify to the occurrence of J-curve phenomenon are Bahmani-Oskooee and Alse (1994), Marwah and Klein (1996), Bahmani-Oskooee and Kantipong (2001), Wilson and Tat (2001), Wilson (2001), Lal and Lowinger (2002), Bahmani-Oskooee and Goswami (2003), Bahmani-Oskooee and Ratha (2004), Narayan and Narayan (2004), Halicioglu (2008) Bahmani-Oskooee and Harvey (2012), Jamilov (2013), Bineau(2016), Vural (2016) and Phong et al. (2018).

The list of studies pertinent to the J-curve phenomenon or the impact of exchange rate on trade balance might be much longer than those previously indicated. Nonetheless, the majority of them assumes

Corresponding Author: Le Hoang Phong, Department of Finance and Accounting Management, Ho Chi Minh City University of Law, Ho Chi Minh City, Vietnam 
linearity in the relationship between exchange rate and trade balance (Bahmani-Oskooee and Fariditavana, 2015, 2016). Specifically, linearity denotes that exchange rate depreciation and appreciation impact trade balance at the same magnitude (i.e., $1 \%$ increase and $1 \%$ decrease of exchange rate cause the same effect on trade balance) and thus, it is also considered as "symmetry". The response of trade balance, however are possibly asymmetric (i.e., trade balance is influenced by $1 \%$ increase and $1 \%$ decrease of exchange rate differently) which is analogous to many other economic variables in terms of asymmetrical adjustment behavior. Bahmani-Oskooee and Fariditavana (2015) provides the proof of nonlinear link between trade balance and exchange rate in 4 countries including Canada, China, Japan and United States which goes in line with the findings of BahmaniOskooee and Fariditavana (2016) for the case of US in bilateral trade with Canada, France, Germany, Italy, Japan and United Kingdom. Also, Nusair reports nonlinearity in the causation of real exchange rate on trade balance in European transitional economies.

The aim of this study is to examine the asymmetrical relationship between the real exchange rate and the trade balance of Vietnam. There are two main reasons for researching this issue. Firstly, all prior studies in Vietnam employ linear models to analyze adjustment process between the exchange rate and the trade balance while the nonlinearity aspect is still unexplored. Secondly, Vietnam is a country changing from centrally-planned economy into market-driven one which faces many challenges such as macroeconomic stabilization, capital account openness, market liberalization and institutional reform for congruent competitiveness. Hence, macroeconomic policies are vital for the aforementioned difficulties and one of the requisites is controlling the relationship between trade balance and exchange rate.

\section{MATERIALS AND METHODS}

We derive the empirical model from Rose and Yellen (1989), Onafowora (2003) and Bahmani-Oskooee and Fariditavana (2016) where trade balance is primarily determined by real effective exchange rate, domestic income and Foreign income:

$$
\begin{aligned}
& \operatorname{LnTB}_{t}=\alpha+\beta_{1} \times \operatorname{LnREER}_{\mathrm{t}}+\beta_{2} \times \\
& \operatorname{LnGDP}_{\mathrm{t}}+\beta_{3} \times \operatorname{LnGDPF}_{\mathrm{t}}+\varepsilon_{\mathrm{t}}
\end{aligned}
$$

In Eq. 1, TB, REER, GDP and GDPF denote Trade Balance, Real Effective Exchange Rate, Domestic output and Foreign output, respectively. REER is designated as the proxy for real exchange rate because it can measure the value of VND in relation to the currencies of Vietnam's major trading partners.

Equation 1 indicates the long-run relationship among the variables and we expect $\beta_{1}$ to be positive which implies the accrual of Vietnam's trade balance in the long run associated with VND devaluation.

We convert Eq. 1 to the Unrestricted Error Correction Model (UECM) form of ARDL proposed by Pesaran et al. (1996, 2001) and Pesaran and Shin (1999):

$$
\begin{aligned}
& \Delta \operatorname{LnTB}_{\mathrm{t}}=\alpha+\sum_{\mathrm{i}=1}^{\mathrm{p}_{0}} \beta_{0, \mathrm{i}} \Delta \operatorname{LnTB}_{\mathrm{t}-\mathrm{i}}+\sum_{\mathrm{j}=0}^{\mathrm{p}_{1}} \beta_{1, j} \Delta \operatorname{LnREER}_{\mathrm{t}-\mathrm{j}}+ \\
& \sum_{\mathrm{k}=0}^{\mathrm{p}_{2}} \beta_{2, \mathrm{k}} \Delta \operatorname{LnGDP}_{\mathrm{t}-\mathrm{k}}+\sum_{1=0}^{\mathrm{p}_{3}} \beta_{3,1} \Delta \operatorname{LnGDPF}_{\mathrm{t}-1}+\lambda_{0} \operatorname{LnTB}_{\mathrm{t}-1}+ \\
& \lambda_{1} \operatorname{LnREER}_{\mathrm{t}-1}+\lambda_{2} \operatorname{LnGDP}_{\mathrm{t}-1}+\lambda_{3} \operatorname{LnGDPF}_{\mathrm{t}-1}+\varepsilon_{\mathrm{t}}
\end{aligned}
$$

The specification in Eq. 2 has an advantage over a standard error-correction model as it allows for the short- and long-run effects of exogenous variables that can be estimated by a one-step OLS procedure. Besides, it has some other superiority: accepting different lag orders of variables, befitting small sample size, allowing variables to be integrated at different orders, generating unbiased estimations in the presence of multicollinearity (Phong et al., 2018).

Both Eq. 1 and 2 demonstrate the linear impact of the determinants on trade balance, implying symmetrical effect. This is nevertheless, impractical as depreciation and appreciation of exchange rate, together with the changes of other independent variables can exert dissimilar influence on trade balance. Accordingly, to overcome this drawback, we employ non-linear autoregressive distributed lag model proposed by Shin et al. (2014) for evaluating asymmetrical effects of the independent variables on Vietnam's trade balance:

$$
\begin{aligned}
& \Delta \operatorname{LnTB}_{\mathrm{t}}=\alpha+\sum_{\mathrm{i}=1}^{\mathrm{p}_{0}} \beta_{0, \mathrm{i}} \Delta \operatorname{LnTB}_{\mathrm{t}-\mathrm{i}}+\sum_{\mathrm{j}=0}^{\mathrm{p}_{1}^{+}} \beta_{1, j}^{+} \Delta \operatorname{LnREER}_{\mathrm{t}-\mathrm{j}}^{+}+ \\
& \sum_{\mathrm{j}=0}^{\mathrm{p}_{1}^{-}} \beta_{1, j}^{-} \Delta \operatorname{LnREER}_{\mathrm{t}-\mathrm{j}}^{-}+\sum_{\mathrm{k}=0}^{\mathrm{p}_{2}^{+}} \beta_{2, \mathrm{k}}^{+} \Delta \operatorname{LnGDP}_{\mathrm{t}-\mathrm{k}}^{+}+ \\
& \sum_{\mathrm{k}=0}^{\mathrm{p}_{\overline{2}}} \beta_{2, \mathrm{k}}^{-} \Delta \operatorname{LnGDP}_{\mathrm{t}-\mathrm{k}}^{-}+\sum_{1=0}^{\mathrm{p}_{3}^{+}} \beta_{3,1}^{+} \Delta \operatorname{LnGDPF}_{\mathrm{t}-1}^{+}+ \\
& \sum_{1=0}^{\mathrm{p}_{3}^{-}} \beta_{3,1} \Delta \operatorname{LnGDPF}_{\mathrm{t}-1}^{-}+\lambda_{0} \operatorname{LnTB}_{\mathrm{t}-1}+\lambda_{1}^{+} \operatorname{LnREER}_{\mathrm{t}-1}^{+}+ \\
& \lambda_{1}^{-} \operatorname{LnREER}_{\mathrm{t}-1}^{-}+\lambda_{2}^{+} \operatorname{LnGDP}_{\mathrm{t}-1}^{+}+\lambda_{2}^{-} \operatorname{LnGDP}_{\mathrm{t}-1}^{-}+ \\
& \lambda_{3}^{+} \operatorname{LnGDPF}_{\mathrm{t}-1}^{+}+\lambda_{3} \operatorname{LnGDPF}_{\mathrm{t}-1}^{-}+\varepsilon_{\mathrm{t}}
\end{aligned}
$$


The independent variables in Eq. 3 are separated into the partial sum processes of positive and negative changesas follows:

$$
\begin{aligned}
& \operatorname{LnREER}_{\mathrm{t}}^{+}=\sum_{\mathrm{i}=1}^{\mathrm{t}} \Delta \operatorname{LnREER}_{\mathrm{i}}^{+}=\sum_{\mathrm{i}=1}^{\mathrm{t}} \max \left(\Delta \operatorname{LnREER}_{\mathrm{i}} ; 0\right) \\
& \operatorname{LnREER}_{\mathrm{t}}^{-}=\sum_{\mathrm{i}=1}^{\mathrm{t}} \Delta \operatorname{LnREER}_{\mathrm{i}}^{-}=\sum_{\mathrm{i}=1}^{\mathrm{t}} \min \left(\Delta \operatorname{LnREER}_{\mathrm{i}} ; 0\right) \\
& \operatorname{LnGDP}_{t}^{+}=\sum_{i=1}^{t} \Delta \operatorname{LnGDP}_{i}^{+}=\sum_{i=1}^{t} \max \left(\Delta \operatorname{LnGDP}_{i} ; 0\right) \\
& \operatorname{LnGDP}_{t}^{-}=\sum_{i=1}^{\mathrm{t}} \Delta \operatorname{LnGDP}_{\mathrm{i}}^{-}=\sum_{\mathrm{i}=1}^{\mathrm{t}} \min \left(\Delta \operatorname{LnGDP}_{\mathrm{i}} ; 0\right) \\
& \operatorname{LnGDPF}_{\mathrm{t}}^{+}=\sum_{\mathrm{i}=1}^{\mathrm{t}} \Delta \mathrm{LnGDPF}_{\mathrm{i}}^{+}=\sum_{\mathrm{i}=1}^{\mathrm{t}} \max \left(\Delta \operatorname{LnGDPF}_{\mathrm{i}} ; 0\right) \\
& \operatorname{LnGDPF}_{\mathrm{t}}^{-}=\sum_{\mathrm{i}=1}^{\mathrm{t}} \Delta \mathrm{LnGDPF}_{\mathrm{i}}^{-}=\sum_{\mathrm{i}=1}^{\mathrm{t}} \min \left(\Delta \operatorname{LnGDPF}_{\mathrm{i}} ; 0\right)
\end{aligned}
$$

Equation 4 displays a nonlinear ARDL Model which is distinguishable from the linear model exhibited in Eq. 2. According to Shin et al. (2014), the approach for testing cointegration in Eq. 4 is not dissimilar from the method suggested by Pesaran et al. (2001) for linear model. In the following study we present further details about the estimation procedure as well as the discussion regarding the outcomes of NARDL Model.

\section{RESULTS AND DISCUSSION}

We estimate the nonlinear model in Eq. 4 for Vietnam's trade balance by utilizing quarterly data from several sources including International Monetary Fund (International Financial Statistics and Direction of Trade Statistics data), World Bank, Federal Reserve Bank of St. Louis, Department of Statistics Malaysia, Philippine Statistics Authority, Ministry of Trade and Industry Singapore and General Statistics Office of Vietnam. The time range is from 2000-2018Q1. The Trade Balance (TB) is defined as the ratio of Vietnam's export value to import value. GDP is Vietnam's real GDP index. GDPF denotes Foreign real GDP index which is computed based on a weighted average of real GDP indices of 26 main trading partners of Vietnam using total trade shares as weights. Those trading partners include Australia, Austria, Belgium, Brazil, Canada, Hong Kong, China, France, Germany, India, Indonesia, Italy, Japan, Malaysia, Netherlands, Philippines, Russia, Singapore, South Korea, Spain, Sweden, Switzerland, Thailand, Turkey, United Kingdom and United States which occupies over $91.25 \%$ of Vietnam's total trade value during 2000-2018Q1 period. REER is Real Effective Exchange Rate which is computed as the geometric weighted average of bilateral exchange rates between VND and the aforementioned partner's currencies, using trade shares as weights and adjusted by pertinent consumer price indices. All variables are in index forms with base period $2000 \mathrm{Q} 1=100$.

For cointegration test, following Pesaran and Pesaran (1997), we indicate the F-statistics results to investigate the cointegration of the variables. Table 1 gives the F-statistics together with relevant critical values for lag orders at different significance levels.

From Table 1, the F-statistics (4.54) is larger than the upper bound critical value (4.08) at 5\% significance level. Hence, the cointegration (or long-run relationship) between LnTB and its determinants is detected.

Then, according to Schwartz Bayesian Criterion (SBC), the maximum lag order equals 6 , so as to save the degree of freedom. Furthermore, we can identify NARDL $(1,0,2,0,2,0,0)$ shown in Table 2 based on SBC.

The goodness of fit is around 0.98006. This is interpreted that nearly $98 \%$ of the fluctuation in trade balance can be explained by the real effective exchange rate, domestic income and Foreign income. Moreover, our model has no statistical problem as evidenced by the outcome of diagnostic tests.

\section{Results of the diagnostic tests:}

A: Serial correlation: ChiSQ $(1)=0.7556[0.385]$

B: Functional from : ChiSQ (1) $=1.098$ [0.296]

C: Normality: ChiSQ (2) $=0.03267$ [0.984]

D: Heteroscedasticity: ChiSQ $(1)=2.2322$ [0.135]

- A: Lagrange multiplier test of residual serial correlation

- B: Ramsey's RESET test using the square of the fitted values

- C: Based on a test of skewness and kurtosis of residuals

. D: Based on the regression of squared residuals on squared fitted values

. Author's calculation

Table 1: The result of bound tests for cointegration test

\begin{tabular}{lllll}
\hline F-stat $\quad-\cdots--90(\%)-\cdots$ & $-\cdots--95(\%)-\cdots$ & $-\cdots 97.5(\%)-\cdots$ & $\cdots$ \\
\hline
\end{tabular}
$\begin{array}{llllllll}\text { I (0) } & \text { I (1) } & \text { I (0) } & \text { I (1) } & \text { I (0) } & \text { I (1) } & \text { I (0) } & \text { I (1) }\end{array}$

\begin{tabular}{|c|c|c|}
\hline Variables & Coefficients & t-statistic \\
\hline LnTB $_{\mathrm{t} 1}$ & 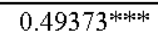 & 4.6561 \\
\hline LnREER $_{t}^{+}$ & $0.42291^{*}$ & 1.8036 \\
\hline LnREER $_{t-1}^{+}$ & $-0.69160^{\text {**** }}$ & -2.4112 \\
\hline $\operatorname{LnREER}_{t 2}^{+}$ & $0.95235^{\text {****** }}$ & 3.7782 \\
\hline LnREER $_{t}^{-}$ & $0.39455^{\text {*k*kak }}$ & 2.8105 \\
\hline $\operatorname{LnGDP}^{+}{ }_{t}^{+}$ & $0.39436^{*}$ & 1.6955 \\
\hline $\operatorname{LnGDP}_{\mathrm{t}}^{-}$ & $-0.54146^{* * 2 * k}$ & -2.4487 \\
\hline $\operatorname{LnGDP}_{t-1}^{-}$ & -0.060579 & -0.7176 \\
\hline LnGDP $_{t 2}^{-}$ & $-0.60203^{\text {*atenes }}$ & -5.4535 \\
\hline $\operatorname{LnGDPF}^{+}{ }_{t}$ & 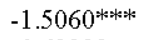 & -3.9841 \\
\hline LnGDPF $_{t}^{-}$ & -0.63322 & -0.9105 \\
\hline Trend & $-0.14078^{\text {sestenes }}$ & -3.6450 \\
\hline Constant & $2.7155^{\text {*esterses }}$ & 5.7807 \\
\hline
\end{tabular}
$\begin{array}{lllllllll}4.54^{* * * *} & 2.57 & 3.64 & 2.94 & 4.08 & 3.27 & 4.49 & 3.66 & 4.97\end{array}$ The asterisks *** is the $5 \%$ significance level; Researchers collection and calculation

Table 2: Results of asymmetric ARDL Model estimation (Dependent variable: $\mathrm{LnTB}$ ) 


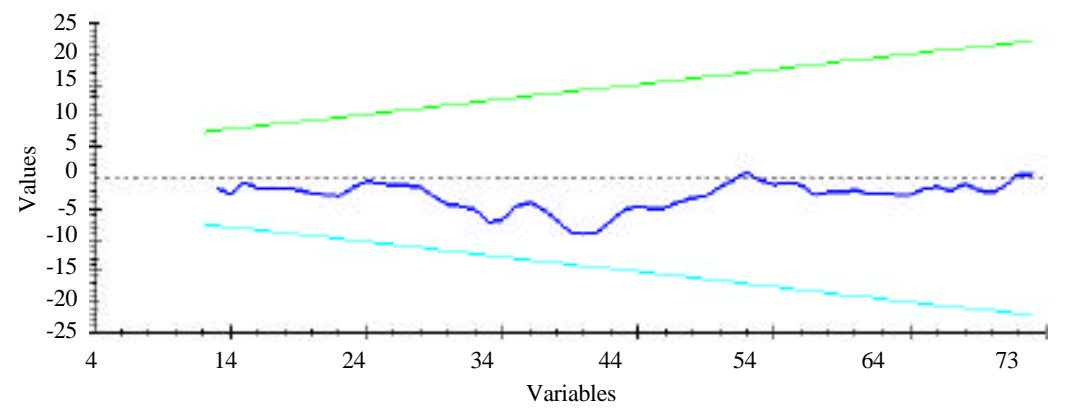

Fig. 1: Plot of Cumulative Sum of recursive residuals (CUSUM) (The straight lines represent critical bounds at 5\% significance level)

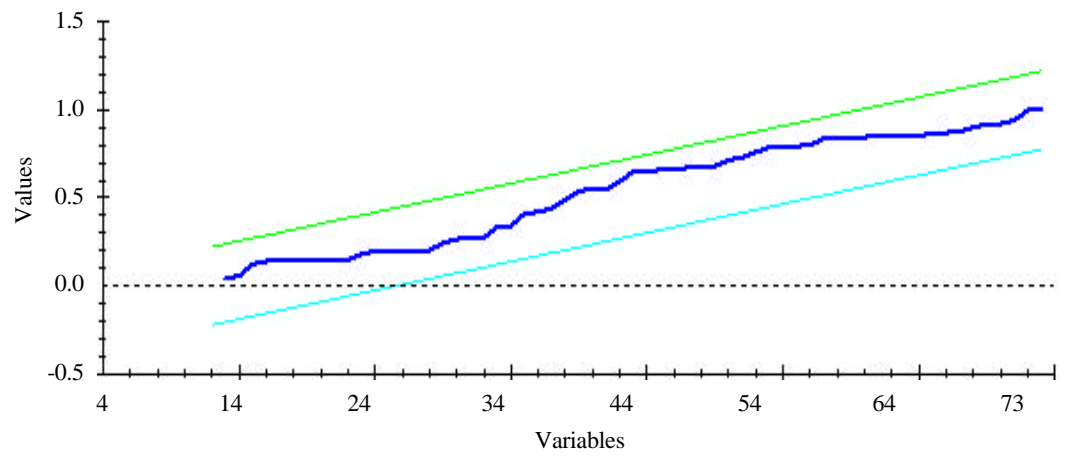

Fig. 2: Plot of Cumulative Sum of Squares of recursive residuals (CUSUMSQ) (The straight lines represent critical bounds at $5 \%$ significance level)

Table 3: Result of asymmetric long-run coefficients (Dependent variable:

\begin{tabular}{llr}
\multicolumn{1}{c}{ LnTB) } & & \\
\hline Variables & Coefficients & t-statistic \\
\hline LnREER $^{+}$ & $1.3504^{* * * * * * *}$ & 3.7063 \\
LnREER $_{t}$ & $0.77933^{* * * *}$ & 2.5862 \\
LnGDP $^{+}$ & $0.77895^{* *}$ & 1.8272 \\
LnGDP $_{t}$ & $-2.3783^{* * * *}$ & -2.5139 \\
LnGDPF $^{+}$ & $-2.9748^{* * * * *}$ & -3.3872 \\
LnGDPF $^{*}$ & -1.2508 & -0.91047 \\
Trend & $-0.27808^{* * * * * *}$ & -2.9293 \\
Constant & $5.3637^{\text {****** }}$ & 18.1881 \\
\hline
\end{tabular}

Following Pesaran et al. (2001), we report the CUSUM and CUSUMSQ tests for the residuals to verify the stability of the short-run and long-run estimates (Fig. 1 and 2).

Conspicuously, at $5 \%$ significance level, the lines denoting CUSUM (Cumulative Sum of recursive residuals) and CUSUMSQ (Cumulative Sum of Square of recursive residuals) stay inside the critical bounds and therefore, the stability and reliability of our model in estimating the short-run and long-run coefficients are unimpeachable.

Table 3 and 4 report the estimation of asymmetric short-run and long-run coefficients from our NARDL Model.

Being negative and statistically significant at $1 \%$ level, the error correction term $\mathrm{EC}_{\mathrm{t}-1}$ can reveal the speed
Table 4: Result of asymmetric short-run coefficients

\begin{tabular}{|c|c|c|}
\hline Variables & Coefficient & t-statistic \\
\hline$\overline{\Delta L n R E E R}_{t}^{+}$ & $0.42291^{*}$ & 1.8036 \\
\hline$\triangle$ LnREER $_{t}^{+}$ & 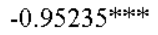 & -3.7782 \\
\hline$\triangle$ LnREER $_{\mathrm{t}}^{-}$ & $0.39455^{\text {*kekek }}$ & 2.8105 \\
\hline$\Delta \operatorname{LnGDP}_{t}^{+}$ & $0.39436^{*}$ & 1.6955 \\
\hline$\Delta \operatorname{LnGDP}_{\mathrm{t}}^{-}$ & $-0.54146^{\text {*e*k }}$ & -2.4487 \\
\hline$\Delta \operatorname{LnGDP}^{+}{ }_{\mathrm{t} 1}$ & $0.60203^{\text {*aserk }}$ & 5.4535 \\
\hline$\Delta \operatorname{LnGDPF}^{+}$ & $-1.5060^{\text {***2*3* }}$ & -3.9841 \\
\hline$\Delta$ LnGDPF- $^{-}$ & -0.63322 & -0.91047 \\
\hline Trend & $-0.14078^{\text {*ateres }}$ & -3.6450 \\
\hline Constant & $2.7155^{\text {*kekesk }}$ & 5.7807 \\
\hline $\mathrm{EC}_{\mathrm{t}-1}$ & $-0.50627^{\text {*kakstak }}$ & -4.7743 \\
\hline$\overline{\mathrm{R}}^{2}$ & 0.77999 & \\
\hline
\end{tabular}

$\overline{\mathrm{R}}^{2}$,*** and ${ }^{* * * * *}$ are respectively the 1,5 and $10 \%$ significance levels

of adjustment from the short run to the long run as well as the cointegration among variables (Phong et al., 2018).

The short-run estimates indicate that LnREER $^{+}$ and $\operatorname{lnREER}$ are dissimilar in terms of lag lengths and values. This illustrates the asymmetric adjustments of the short-run trade balance in the case of Vietnam. Furthermore, both LnREER $^{+}$and LnREER carry statistically significantly positive signs and hence, depreciation or appreciation of VND can improve the trade balance in the long run but the impact of VND depreciation is stronger. Besides, our findings discern nonlinear effects of domestic income and Foreign income on Vietnam's trade balance in both the short run and 
long run. Specifically, the domestic income's negative changes is higher than the positive one. The Foreign income negatively impacts the trade balance in the long-run, suggesting that the incremental outputs of other countries do not absorb Vietnam's goods. The possible culprit is that Vietnam's goods quality is not high and Vietnam is a trade-deficit country.

\section{CONCLUSION}

In this study by using aggregate data and employing non-linear ARDL approach, we find that the real effective exchange rate, domestic income and Foreign income have asymmetrically statistically significant impacts on Vietnam's trade balance in both short-run and long-run.

Additionally, the nonlinear model can separate the effects of VND appreciation and depreciation as well as changes of domestic and Foreign income levels on Vietnam's trade balance which is unidentified by the linear model.

Besides studies by Mohsen Bahmani-Oskooee in manifold countries, this study fills a research gap in examining the nonlinear effects of the determinants of Vietnam's trade balance. As regards the extension of this topic, we propose analyzing the relationship between macroeconomic factors, especially, real exchange rate and trade balance at bilateral level between Vietnam and each trading partner.

\section{RECOMMENDATIONS}

We also perceive that a further disaggregation of bilateral trade data at industry level will probably offer even more detailed insights into the trade balance dynamics. We have included such a query as a part of our future research intention.

\section{ACKNOWLEDGEMENTS}

The researchers gratefully acknowledge Prof. Mohsen Bahmani-Oskooee for inspiring us to fill the gap concerning asymmetric cointegration in assessing the relationship between exchange rate and trade balance for the case of Vietnam.

Moreover, we express our gratitude for the financial support from the University of Economics Ho Chi Minh city, Vietnam for this research. We also thank Prof. Dr. Su Dinh Thanh and Dr. Tran Thi Tuan Anh for helpful support.

\section{REFERENCES}

Bahmani-Oskooee, M. and A. Gelan, 2012. Is there a J-curve effect in Africa?. Intl. Rev. Appl. Econ., 26: 73-81.
Bahmani-Oskooee, M. and A. Ratha, 2004. The J-curve dynamics of U.S. bilateral trade. J. Econ. Finance, 28: 32-38

Bahmani-Oskooee, M. and A.M. Kutan, 2009. The J-curve in the emerging economies of Eastern Europe. Appl. Econ., 41: 2523-2532.

Bahmani-Oskooee, M. and H. Fariditavana, 2015. Nonlinear ARDL approach, asymmetric effects and the J-curve. J. Econ. Stud., 42: 519-530.

Bahmani-Oskooee, M. and H. Fariditavana, 2016. Nonlinear ARDL approach and the J-curve phenomenon. Open Econ. Rev., 27: 51-70.

Bahmani-Oskooee, M. and J. Alse, 1994. Short-run versus long-run effects of devaluation: Error correction modelling and cointegration. Eastern Econ. J., 20: 453-464.

Bahmani-Oskooee, M. and M. Malixi, 1992. More evidence on the J curve from LDCs. J. Policy Model., 14: 641-653.

Bahmani-Oskooee, M. and S.W. Hegerty, 2010. The J-and S-curves: A survey of the recent literature. J. Econ. Studies., 37: 580-596.

Bahmani-Oskooee, M. and T. Kantiapong, 2001. Bilateral J-curve between Thailand and her trading partners. J. Econ. Dev., 26: 107-117.

Bahmani-Oskooee, M. and T.J. Brooks, 1999. Bilateral J-curve between U.S. and her trading partners. Weltwirtschaftliches Arch., 135: 156-165.

Bahmani-Oskooee, M., 1985. Devaluation and the J-curve: Some evidence from LDCs. Rev. Econ. Statist., 71: 500-504.

Bahmani-Oskooee, M., 1989. Devaluation and the J-curve: Some evidence for LDCs; Errata. Rev. Econ. Stat., 71: 553-554.

Bahmani-Oskooee, M.M. and G.G. Goswami, 2003. A disaggregated approach to test the $\mathrm{J}$-curve phenomenon: Japan versus her major trading partners. J. Econ. Finance, 27: 102-113.

Bahmani-Oskooee, M. and H. Harvey, 2012. J-curve: Singapore versus her major trading partners. Econ. Pap. J. Appl. Econ. Policy, 31: 515-522.

Bahmani-Oskooee, M. and Y. Wang, 2006. The J curve: China versus her trading partners. Bull. Econ. Res., 58: 323-343.

Bineau, Y., 2016. Real exchange rate and bilateral trade balance of Cambodia: A panel investigation. Econ. Bull., 36: 895-900.

Georgopoulos, G.J., 2008. The J-curve revisited: An empirical analysis for Canada. Atlantic Econ. J., 36: 315-332.

Halicioglu, F., 2008. The J-curve dynamics of Turkey: An application of ARDL model. Appl. Econ., 40: 2423-2429. 
Hsing, Y. and B.S. Sergi, 2010. Test of the bilateral trade J-curve between the USA and Australia, Canada, New Zealand and the UK. Intl. J. Trade Global Markets, 3: 189-198.

Jamilov, R., 2013. J-curve dynamics and the Marshall-Lerner condition: Evidence from Azerbaijan. Trans. Stud. Rev., 19: 313-323.

Lal, A.K. and T.C. Lowinger, 2002. The J-curve: Evidence from East Asia. J. Econ. Integr., 17: 397-415.

Magee, S.P., 1973. Currency contracts, pass through and devaluation. Brooking Pap. Econ. Act., 1973: 303-325.

Marwah, K. and L.R. Klein, 1996. Estimation of J-curves: United States and Canada. Can. J. Econ., 29: 523-539.

Narayan, P.K. and S. Narayan, 2004. The J-curve: Evidence from Fiji. Intl. Rev. Appl. Econ., 18: 369-380.

Narayan, P.K., 2006. Examining the relationship between trade balance and exchange rate: The case of Chinas trade with the USA. Appl. Econ. Lett., 13: 507510 .

Nusair, S.A., 2017. The J-curve phenomenon in European transition economies: A nonlinear ARDL approach. Intl. Rev. Appl. Econ., 31: 1-27.

Onofowora, O.A., 2003. Exchange rate and trade balance in East Asia: Is there a J-curve. Econ. Bull., 5: 1-13.

Pesaran, H.M., Y. Shin and R.J. Smith, 2001. Bounds testing approaches to the analysis of level relationships. J. Applied Econ., 16: 289-326.

Pesaran, M.H. and B. Pesaran, 1997. Working with Microfit 4.0. Oxford University, England, UK., ISBN-13:9780192685315, Pages: 505.

Pesaran, M.H. and Y. Shin, 1999. An Autoregressive Distributed Lag Modelling Approach to Cointegration Analysis. In: Econometrics and Economic Theory in the 20th Century: The Ragnar Frisch Centennial Symposium, Strom, S. (Ed.). Cambridge University Press, England, UK., pp: $371-413$.
Pesaran, M.H., Y. Shin and R.J. Smith, 1996. Bounds testing approaches to the analysis of level relationships. Master Thesis, Department of Applied Economics, University of Cambridge, Cambridge, England, UK.

Phong, L.H., H.H.G. Bao and D.T.B. Van, 2018. Testing J-Curve Phenomenon in Vietnam: An Autoregressive Distributed Lag (ARDL), Approach. In: Econometrics for Financial Applications, Anh L., L. Dong, V. Kreinovich and N. Thach (Eds.). Springer, Cham, Switzerland, pp: 491-503.

Rose, A.K. and J.L. Yellen, 1989. Is there a J-curve. J. Monetary Econ., 24: 53-68.

Rose, A.K., 1990. Exchange rates and the trade balance: Some evidence from developing countries. Econ. Lett., 34: 271-275.

Rose, A.K., 1991. The role of exchange rates in a popular model of international trade: Does the Marshall-Lerner condition hold?. J. Intl. Econ., 30: 301-316.

Shin, Y., B. Yu and M. Greenwood-Nimmo, 2014. Modelling Asymmetric Cointegration and Dynamic Multipliers in a Nonlinear ARDL Framework. In: Festschrift in Honor of Peter Schmidt: Econometric Methods and Applications, Horrace, W.C. and R.C. Sickles (Eds.). Springer, New York, USA., ISBN:978-1-4899-8007-6, pp: $281-314$.

Vural, B.M.T., 2016. Effect of real exchange rate on trade balance: Commodity level evidence from Turkish bilateral trade data. Procedia Econ. Finance, 38: 499-507.

Wilson, P. and K.C. Tat, 2001. Exchange rates and the trade balance: The case of Singapore 1970-19961. J. Asian Econ., 12: 47-63.

Wilson, P., 2001. Exchange rates and the trade balance for dynamic Asian economies: Does the J-curve exist for Singapore, Malaysia and Korea. Open Econ. Rev., 12: 389-413.

Ziramba, E. and R.T. Chifamba, 2014. The J-curve dynamics of South African trade: Evidence from the ARDL approach. Eur. Sci. J., 10: 346-358. 